\title{
Green Methods Used to Enhance Enzymes
}

\author{
Mihaela D. Leonida \\ Fairleigh Dickinson University, Teaneck, NJ, 07666, USA \\ mleonida@fdu.edu
}

\begin{abstract}
This project focuses on modifying properties of redox enzymes by using green chemistry. Working hypothesis: upon partially unfolding and subsequent refolding enzymes, new moieties can be embedded in their structure. These may confer additional/beneficial properties to the enzyme. Two methods were used to partially unfold the proteins: a) exposure to ionic liquids and b) application of high hydraulic pressure. The redox enzymes modified by exposure to an ionic liquid were lactate dehydrogenase (LDH), cholesterol oxidase (ChOx), and amine oxidase (AO). AO was also modified by transient exposure to high pressure. These are important oxidoreductases used in clinical laboratory, defense, sports medicine, the food industry. The kinetics of electron transfer is important when a redox enzyme is evaluated for an application because its redox centers are buried in insulating protein resulting in slow electron transfer. Since the rate of electron transfer in proteins decays exponentially with the distance donor-acceptor, we decreased the distances between redox centers within the enzyme by molecular alteration of its 3-D structure in the presence of modifiers. The choice of modifiers was tailored to the characteristics of each enzyme. Following the procedure, additional redox centers were entrapped within the protein structure thereby enhancing it. The enzymes were assayed before and after modification to assess the benefits of the procedures. All modified enzymes (ME) retained activity. The ME were tested as biosensing elements for analytical applications and performed well. The proposed methods are inexpensive, environmentally friendly, and enzyme friendly due to the species used as modifiers.
\end{abstract}

\section{Introduction}

Oxidoreductases are needed for analytical applications (in biosensors) and for chiral synthesis of compounds with high enantiomeric purity for the pharmaceutical industry. However the rate of electron transfer in the reactions catalyzed by them is very slow when enzyme electrodes are used. A solution to the problem is the use of mediators to enhance the rate of electron transfer. One successful strategy to achieve this is covalentlybinding redox-active centers (the mediators) to sites on the enzyme. This approach is known in the chemical literature as enzyme "wiring" and it typically results in an important loss in enzyme activity.

Ionic liquids (IL) have gained interest lately due to their unique range of physical and chemical properties, notably their solvent capabilities, negligible vapor pressure and thermal stability [1]. Many commonly-used IL have excellent solvent properties for a wide range of organic, inorganic and organo-metallic compounds [2]. Their ability to dissolve proteins is of particular interest to bioorganic catalysis, IL replacing the traditional organic solvents in some applications [3]. Besides being environmentally unfriendly, organic solvents also affect adversely some suspended proteins [4]. In the present study we reversibly denatured redox enzymes by exposure to an ionic liquid 1-ethyl-3methylimidazolium tetrafluoroborate $\left(\mathrm{emim}-\mathrm{BF}_{4}\right)$. While the enzymes are partially unfolded with the redox centers exposed, they came in contact with species having electron transfer mediating capacity. Upon reversing the denaturation, small mediator molecules were trapped in the tertiary structure of the refolded enzymes which, consequently, become "wired" enzymes.

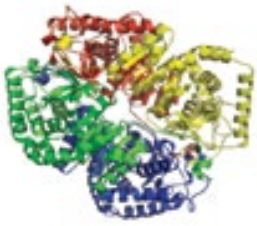

(a)

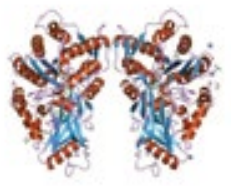

(b)
Figure 1 (a) LDH from rabbit muscle; (b) $\mathrm{ChOx}$ from Brevibacterium sp. 
In the present study lactate dehydrogenase (LDH, Fig. 1a) and cholesterol oxidase (ChOx, Fig. 1b) were modified by transient exposure to emim- $-\mathrm{BF}_{4}$ with and without flavin adenine dinucleotide (FAD) - the prosthetic group of $\mathrm{LDH}$ and $\mathrm{ChOx}$ - present. After removal of the IL by dialysis, the activity of the renatured enzymes was assayed spectrophotometrically. Previous studies have shown the properties of IL to dramatically change in the presence of small quantities of water [5]. Thus, a parallel procedure was conducted in the presence of water and the differences in recovered activities were evaluated in terms of structural changes in the modified enzymes (ME).

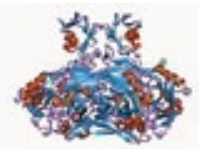

Figure 2. Amine oxidase from $E$. coli

Amine oxidase (AO, Fig.2) is an important oxidoreductase used in analytical applications for clinical laboratory and for the food industry (especially for fish and seafood products). Depending on the natural source, some AO have FAD as a prosthetic group. Some others belong to the copper-enzymes family and are disulfide-linked homodimers. They base their redox properties on a copper (II) ion located near the active site (close to the center of the homodimer) which is coordinated by three histidine residues. Also involved in the redox action of $\mathrm{AO}$ is a tyrosine residue that has been modified into topa-quinone (TPQ), which is also a cofactor in copper amine oxidases. As modifiers used during high pressure exposure we investigated several directions due to the versatility of this enzyme. In one experiment we used $\mathrm{Cu}^{2+}$ ions and in a parallel one pyridoxal phosphate (PLP, closely related to TPQ, but less expensive), targeting enhanced stability and improved kinetics of electron transfer. Since there are AO species having FAD as cofactor, another experiment used FAD as modifier. Based on new literature mentioning copper enzymes as potential cardioprotective agents for heart patients, a modification of AO was conducted in the presence of $\alpha$-lipoic acid (LA), agent with strong antioxidant properties and reliable electrochemical activity. This experiment targeted both enhanced kinetics and potential for therapeutic use.
AO was "wired" using another green method as well, reagentless (mechanical) reversible modification of enzyme tertiary structure using high hydraulic pressure. Like the first method (using IL) this environmently-friendly procedure targeted several $\mathrm{AO}$ properties: a) increased stability; b) enhanced kinetics of electron transfer; c) enhancement of antioxidant action. After the modification procedures all $\mathrm{ME}$ were lyophilized and stored at $-20{ }^{\circ} \mathrm{C}$.

\section{Results and discussion}

LDH and ChOx were modified in parallel procedures: using different enzyme:IL ratios, with/without FAD present, with/without additional water present. The ME were assayed after overnight dialysis. All modified $\mathrm{LDH}$ and $\mathrm{ChOx}$ retained activity following the denaturation-renaturation procedures. The results are summarized in Table 1 for $\mathrm{LDH}$ and in Table 2 for $\mathrm{ChOx}$.

Table 1. Enzymatic activityof LDH (kU) before and after exposure to emim- $\mathrm{BF}_{4}$ a) no water added; b) with $5 \%$ water added to modifying mixture

a)"Wiring" LDH without water present

\begin{tabular}{|lcccc|}
\hline Ratio & \multicolumn{4}{c|}{ no water added } \\
LDH/IL & \multicolumn{2}{c}{ with FAD } & \multicolumn{2}{c|}{ no FAD } \\
$\mathrm{kU} / \mathrm{mg}$ & initial & final & initial & final \\
& & & & \\
\hline 5.00 & 0.0692 & 0.0996 & 0.0763 & 0.1465 \\
& & & & \\
\hline 6.67 & 0.0377 & 0.2236 & 0.012 & 0.2722 \\
\hline 10.00 & 0.1131 & 0.2625 & 0.0151 & 0.0008 \\
\hline
\end{tabular}

b) "Wiring" LDH in the presence of 5\% water

\begin{tabular}{|lcccc|}
\hline Ratio & \multicolumn{4}{c|}{ with $5 \% \mathrm{w} / \mathrm{v}$ water added } \\
$\mathrm{LDH} / \mathrm{IL}$ & \multicolumn{2}{c}{ with FAD } & \multicolumn{2}{c|}{ no FAD } \\
$\mathrm{kU} / \mathrm{mg}$ & initial & final & initial & final \\
& & & & \\
\hline 5.00 & 0.1247 & 0.3163 & 0.1093 & 0.3401 \\
& & & & \\
\hline 6.67 & 0.1089 & 1.0298 & 0.1363 & 0.6576 \\
\hline 10.00 & 0.1052 & 1.4534 & 0.1391 & 0.2977 \\
\hline
\end{tabular}


c)Enhancement (factors) due to LDH "wiring"

\begin{tabular}{|lcccc|}
\hline Ratio & $\begin{array}{l}\text { no water added } \\
\text { added }\end{array}$ & & with 5\% w/v water \\
LDH/IL & with FAD & no FAD & with FAD & no FAD \\
$\mathrm{kU} / \mathrm{mg}$ & $\begin{array}{c}\text { Final/ } \\
\text { initial }\end{array}$ & $\begin{array}{c}\text { Final/ } \\
\text { initial }\end{array}$ & $\begin{array}{c}\text { Final/ } \\
\text { initial }\end{array}$ & $\begin{array}{c}\text { Final/ } \\
\text { initial }\end{array}$ \\
\hline 5.00 & 1.44 & 1.92 & 2.54 & 3.11 \\
\hline 6.67 & 5.93 & 22.68 & 9.46 & 4.82 \\
\hline 10.00 & 2.32 & $(0.05)$ & 13.82 & 2.14 \\
\hline
\end{tabular}

The enzyme changes structure upon exposure to IL and then again, upon removal of IL. The transient exposure to IL triggers enzyme denaturation and the removal of the IL by dialysis induces a second alteration, resulting in a refolded enzyme. Lozano et al. [6] proposed a molecular mechanism of enzyme stabilization in ionic liquids and attributed stability and increased activity to the preservation of essential water in the enzyme's microenvironment. This study lends support to the concept of an altered enzyme structure formed upon suspension in the IL and a second change upon removal of IL in which the tertiary structure is partially restored. The increase in catalytic activity can be attributed to the combination of two mechanisms: a) an altered 3-D structure with a more favorable spatial arrangement, formed upon removal of IL, with increased exposure and interaction of an increased number of prosthetic groups with the substrate. The increase in activity in all samples supports the concept of residual alteration of $\mathrm{LDH}$ into a non-native structure, the increased activity of which is independent of the effects of molecular "wiring". Such alteration can result from interaction of the enzyme with the anion $\left(\mathrm{BF}_{4}^{-}\right)$[7], which is a chaotrope that affects the structural water of the enzyme [8].

Also at work is the chaotropic cation emim $^{+}$, and this would explain the appearance of an optimum LDH/IL ratio for enzyme activity, as result of the competition between the two groups for structural water. The second possible mechanism is: b) the entrapment of FAD molecules within the structure of $\mathrm{LDH} / \mathrm{ChOx}$ affords a molecular "wire" to the enzyme. Entrapping the FAD within the $\mathrm{LDH} / \mathrm{ChOx}$ requires noncovalent modification of the enzyme structure. Possibly, a more open configuration is achieved during suspension in IL, by virtue of the hydrogen-bonding properties of the anion under investigation $\left(\mathrm{BF}_{4}^{-}\right)$[6]. Stronger hydrogen bonding anions might have resulted in irreversible loss of catalytic activity due to a permanently bound anion to the peptide backbone of certain enzymes. Upon removal of the IL, a more compact, active, native-like configuration is achieved in which the FAD remaining in the ME is entrapped within the enzyme and enhances the kinetics of the electron transfer which translates into a higher activity for LDH. The more modest enhancement afforded by FAD as a molecular "wire" within ChOx was correleted with the status of FAD present in the native enzymes: noncovalently bound in LDH and both noncovalently and covalently (less stable) bound in ChOx.

Table 2. Characterization of the modified $\mathrm{ChOx}$

\begin{tabular}{|c|c|c|c|c|}
\hline $\begin{array}{c}\text { Ratio } \\
\text { mg } \\
\begin{array}{c}\text { ChOx to } \\
\text { ml IL }\end{array}\end{array}$ & $\begin{array}{c}\text { FAD } \\
(\mathrm{mg})\end{array}$ & $\begin{array}{c}\text { Activity } \\
\text { ME } \\
(\% \\
\text { initial })\end{array}$ & $\begin{array}{c}\text { Increase in } \\
\text { activity } \\
\text { due to FAD } \\
(\%)\end{array}$ & $\begin{array}{c}\text { Increase } \\
\text { in } \\
\text { peak } \\
\text { current } \\
(\%)\end{array}$ \\
\hline $\begin{array}{c}3.8: 0.25 \\
\text { No water }\end{array}$ & 0 & 25.3 & - & - \\
\hline $\begin{array}{c}3.8: 0.25 \\
\text { No water }\end{array}$ & 0.89 & 45.8 & 81.53 & 74.70 \\
\hline $\begin{array}{c}3.8: 0.25 \\
\text { No water }\end{array}$ & 0 & 22.5 & - & - \\
\hline $\begin{array}{c}3.8: 0.25 \\
\text { No water }\end{array}$ & 1.65 & 28.9 & 28.04 & 33.35 \\
\hline $\begin{array}{c}3.8: 0.25 \\
5 \% \\
\text { water }\end{array}$ & 0 & 35.8 & - & - \\
\hline $\begin{array}{c}3.8: 0.25 \\
5 \% \\
\text { water }\end{array}$ & 0.89 & 46.2 & 29.11 & 34.55 \\
\hline $\begin{array}{c}3.8: 0.25 \\
5 \%\end{array}$ & 0 & 43.5 & - & - \\
water & & & & \\
\hline $\begin{array}{c}3.8: 0.25 \\
5 \% \\
\text { water }\end{array}$ & 1.65 & 78.0 & 79.35 & 144.86 \\
\hline
\end{tabular}

The lactate biosensors built with ME-LDH showed higher catalytic effects than the non-wired one (using FAD as mediator added to the solution) 
and linearity in lactate concentration (Figure $3 \mathrm{a}$ and b). The biosensor built with the ME-ChOx showed catalytic effect (Table 2) and linearity in cholesterol concentration as well.

(a)

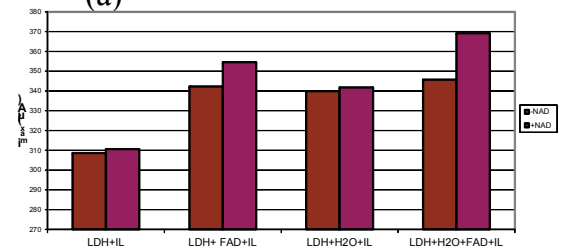

(b)

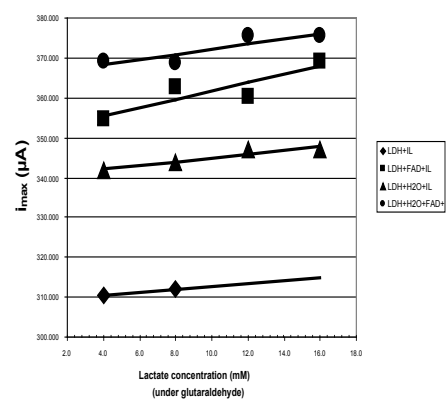

Figure 3. ME-LDH as biosensing element: a) catalytic effect; b) linearity in lactate concentration.

Table 3. Enhancement and stabilization of ME-AO

\begin{tabular}{|c|c|c|c|}
\hline $\begin{array}{c}\text { ME-AO } \\
\text { modifier }\end{array}$ & $\begin{array}{c}\text { Activity } \\
\text { Dec. 2014 } \\
\text { (U) }\end{array}$ & $\begin{array}{c}\text { Activity } \\
\text { Sept. 2015 } \\
\text { (U) }\end{array}$ & $\begin{array}{c}\text { Residual } \\
\text { activity } \\
(\%)\end{array}$ \\
\hline Native & - & - & 7.56 \\
\hline FAD & $5.68 * 10^{-5}$ & $3.90 * 10^{-5}$ & 68.7 \\
\hline PLP & $1.78 * 10^{-4}$ & $1,87 * 10^{-5}$ & 10.5 \\
\hline $\mathrm{CuSO}_{4}$ & $2.08 * 10^{-4}$ & $8.89 * 10^{-6}$ & 4.27 \\
\hline $\mathrm{LA}$ & $4.44 * 10^{-5}$ & $7.55 * 10^{-5}$ & 170.3 \\
\hline $\begin{array}{c}\mathrm{FAD}+ \\
\mathrm{CuSO}\end{array}$ & $2.13 * 10^{-4}$ & $3.27 * 10^{-4}$ & 153.3 \\
\hline FAD+LA & $8.88 * 10^{-5}$ & $1.19 * 10^{-4}$ & 133.8 \\
\hline $\begin{array}{c}\text { PLP+ } \\
\text { CuSO }\end{array}$ & $1.47 * 10^{-4}$ & $1.78 * 10^{-5}$ & 12.1 \\
\hline PLP+LA & $1.51 * 10^{-4}$ & $2.25 * 10^{-6}$ & 1.5 \\
\hline
\end{tabular}

Following modification in the presence of one modifier or a binary combination thereof, all ME-AO retained activity. The results are presented in Table 3 together with the remarkable values of the activity and residual activity after 9 months. The most enhancement was afforded by the modification done in the presence of $\mathrm{PLP}+\mathrm{CuSO}_{4}$. Taking into account that a biosensor based on ME-AO modified with $\mathrm{PLP}+\mathrm{CuSO}_{4}$ showed good catalytic effect and linearity as a function of benzylamine concentration, this enzyme-friendly procedure for AO "wiring" shows promise for analytical applications.

Table 4. Activity of AO modified at $325 \mathrm{MPa}$

\begin{tabular}{|c|c|c|c|c|}
\hline $\begin{array}{c}\text { Modifier/ } \\
\text { Modification } \\
\text { time }\end{array}$ & $\begin{array}{c}\text { Activities } \\
\text { (U) }\end{array}$ & $\begin{array}{c}\text { Adjusted } \\
\text { Activity* } \\
\text { (U) }\end{array}$ & $\begin{array}{c}\text { Residual } \\
\text { Activity } \\
\text { (vs. } \\
\text { Native) } \\
\%\end{array}$ & \begin{tabular}{|c|} 
Residual \\
Activity \\
(Modifier \\
Effect) \\
$\%$
\end{tabular} \\
\hline Native & $5.033 * 10^{-5}$ & $1.678 * 10^{-4}$ & - & - \\
\hline Native $/ 1 \mathrm{~h}$ & $2.862 * 10^{-5}$ & $9.540 * 10^{-5}$ & 56.87 & - \\
\hline FAD / 1h & $2.466^{*} 10^{-5}$ & $8.220 * 10^{-5}$ & 48.99 & 86.16 \\
\hline $\mathrm{PLP} / 1 \mathrm{~h}$ & $2.345 * 10^{-4}$ & $7.817 * 10^{-4}$ & 465.9 & 819.4 \\
\hline $\mathrm{CuSO}_{4} / 1 \mathrm{~h}$ & $1.890 * 10^{-4}$ & $6.300 * 10^{-4}$ & 375.6 & 660.5 \\
\hline $\mathrm{LA} / 1 \mathrm{~h}$ & $1.292 * 10^{-4}$ & $4.307 * 10^{-4}$ & 256.8 & 451.6 \\
\hline Native / $30 \mathrm{~min}$ & $5.404 * 10^{-5}$ & $1.801 * 10^{-4}$ & 107.4 & - \\
\hline $\mathrm{FAD} / 30 \mathrm{~min}$ & $1.087 * 10^{-4}$ & $3.623 * 10^{-4}$ & 216.0 & 201.2 \\
\hline PLP / $30 \mathrm{~min}$ & $3.944 * 10^{-4}$ & $1.315 * 10^{-3}$ & 783.6 & 729.8 \\
\hline $\mathrm{CuSO}_{4} / 30 \mathrm{~min}$ & $7.952 * 10^{-4}$ & $2.651 * 10^{-3}$ & 1580.0 & 1471.4 \\
\hline $\mathrm{LA} / 30 \mathrm{~min}$ & $2.537 * 10^{-4}$ & $8.457 * 10^{-4}$ & 504.1 & 469.4 \\
\hline
\end{tabular}

*Compared to the native $\mathrm{AO}$ after compression followed by lyophilization.

Using another environmentally- and enzyme-friendly approach, AO was modified through a reagentless (mechanical) procedure where high hydraulic pressure $(325 \mathrm{MPa})$ was applied transiently with/without modifier present. Two parallel modifications were conducted using 2 different compression times, $1 \mathrm{~h}$ and $30 \mathrm{~min}$, respectively. The same single modifiers were used ( $\left.\mathrm{FAD} / \mathrm{PLP} / \mathrm{CuSO}_{4} / \mathrm{LA}\right)$. The results are presented in Table 4. The relative activities were calculated in relation with the native enzyme and also in relation to the native enzyme subjected to high 
pressure and then lyophilized (adjusted activity, since $70 \%$ of activity is lost following lyophilization). All ME (with one exception) showed remarkable residual activities, higher than that of the native enzyme processed at high pressure followed by lyophilization. Similarly to the "wiring" done in the presence of IL, the highest enhancement was afforded by PLP and $\mathrm{CuSO}_{4}$, species intrinsic to AO. Shorter times used to apply pressure resulted in more significant enhancement.

ME-AO were tested (preliminary) for antioxidant action as well. All showed significant effect. The modification done in the presence of LA did not afford the highest effect, as expected Table 5 displays the antioxidant activities of the ME-AO expressed as antioxidant effect equivalent to that of a certain concentration of a Trolox solution (water soluble analog of vitamin E.

Table 5. Antioxidant activity of ME-AO

\begin{tabular}{|c|c|}
\hline $\begin{array}{c}\text { Modifier / } \\
\text { Modification time }\end{array}$ & $\begin{array}{c}\text { Antioxidant } \\
\text { activity } \\
\text { (mM Trolox) }\end{array}$ \\
\hline No modifier / 1 h & 1.416 \\
\hline $\mathrm{FAD} / 1 \mathrm{~h}$ & 1.935 \\
\hline $\mathrm{PLP} / 1 \mathrm{~h}$ & 1.221 \\
\hline $\mathrm{CuSO} / 1 \mathrm{~h}$ & 1.188 \\
\hline $\mathrm{LA} / 1 \mathrm{~h}$ & 0.117 \\
\hline $\begin{array}{c}\text { No modifier } / 30 \\
\text { min }\end{array}$ & 2.455 \\
\hline $\mathrm{FAD} / 30$ min & 1.513 \\
\hline $\mathrm{PLP} / 30$ min & 1.675 \\
\hline $\mathrm{CuSO} / 30$ min & 0.831 \\
\hline $\mathrm{LA}_{4} / 30 \mathrm{~min}$ & 1.123 \\
\hline
\end{tabular}

Table 6 shows a comparison between the two green procedures for oxidoreductase enhancement proposed herein. While both afforded enhancement to $\mathrm{AO}$, the modification conducted by applying high hydraulic pressure for shorter time (30 min) seems better if expense vs. resulting enhancement is considered. The use of binary combinations of modifiers compared to single modifiers results in less enhancement in ME-AO compared to benefit of using $30 \mathrm{~min}$ vs. $1 \mathrm{~h}$ exposure to high hydraulic pressure in the presence of one modifier.

Table 6. Comparison between modification methods for AO: using exposure to IL (single/binary modifier) vs. application of high pressure for $1 \mathrm{~h} / 30 \mathrm{~min}$.

\begin{tabular}{|c|c|c|c|c|c|}
\hline $\begin{array}{l}\text { AO } \\
\text { Modi } \\
\text { fier }\end{array}$ & $\begin{array}{c}\text { Residual } \\
\text { Activity \% } \\
\text { (IL) }\end{array}$ & \begin{tabular}{|c|} 
Resi \\
dual \\
Acti \\
vity \\
$\%$ \\
$(1$ hour $)$
\end{tabular} & \begin{tabular}{|c|} 
Resi \\
dual \\
Acti \\
vity \\
$\%$ \\
(30 min)
\end{tabular} & \begin{tabular}{|c} 
Resi \\
dual Acti \\
vity \\
$\%$ \\
$\left(+\mathrm{Cu}^{2+}\right)^{*}$
\end{tabular} & $\begin{array}{c}\text { Resi } \\
\text { dual Acti } \\
\text { vity } \\
\% \\
(+ \text { LA)* }\end{array}$ \\
\hline FAD & 54.96 & 48.99 & 216.0 & 206.1 & 85.88 \\
\hline PLP & 171.8 & 465.9 & 783.6 & 142.2 & 145.7 \\
\hline
\end{tabular}

*Modification using IL exposure

The methods presented for oxidoreductase enhancement resulted in molecularly modified enzymes with strong self-mediating capability. In none of the biosensors studied was ascorbate interference observed. The fact that the procedures are environment-friendly and the level of enhancement they afforded (activity and stability) recommends them for use in analytical applications. The use of high hydraulic pressure for enzyme "wiring" is a very inexpensive, green procedure highly recommended by these preliminary data.

\section{Acknowledgment}

Thanks are due to Prof. Catherine Royer from RPI for allowing access to the hydraulic press.

\section{References}

1) Welton, T., Chem. Rev. (1999) 99, 2071.

2) Poole, C.F., J. Chromatography (2004) 1037, 49.

3) DiCarlo et al, Bioelectrochem (2006) 68,134.

4) Gorman, L.S., Dordick J.S., Biotechnol. Bioeng. (1992) 39, 392.

5) Fujita, K. et al, Biotechnol. Bioeng. (2006) 94, 1209.

6) Lozano, P. et al.Biocat Biotransf (2005) 23, 169.

7) Khmelnitsky, L et al., Eur. J. Biochem.,(1991) 198, 31.

8) Zhao, H., J. Chem. Technol. Biotechnol., (2006) 81, 877. 